Journal of Phycology

December 2017, Volume 53, Issue 6, Pages 1193-1205

http://dx.doi.org/10.1111/jpy.12582

http://archimer.ifremer.fr/doc/00398/50971/

(c) 2017 Phycological Society of America

\title{
First record of resting cysts of the benthic dinoflagellate Prorocentrum leve in a natural reservoir in Gujan-Mestras, Gironde, France
}

\author{
Mertens Kenneth ${ }^{1,{ }^{*}}$, Gu Haifeng ${ }^{2}$, Pospelova Vera ${ }^{3}$, Chomérat Nicolas ${ }^{1}$, Nézan Elisabeth ${ }^{1}$, \\ Gurdebeke Pieter ${ }^{4}$, Bogus Kara ${ }^{5}$, Vrielinck Henk ${ }^{6}$, Rumebe Myriam ${ }^{7}$, Meteigner Claire ${ }^{7}$
}

${ }^{1}$ Ifremer LER BO; Station de Biologie Marine; Place de la Croix, BP40537 F-29185 Concarneau Cedex, France

2 Third Institute of Oceanography; SOA; Xiamen 361005, China

${ }^{3}$ School of Earth and Ocean Sciences; University of Victoria; PO Box 1700, STN CSCVictoria British

Columbia ,Canada

${ }^{4}$ Research Unit Palaeontology; Department of Geology; Ghent University; Krijgslaan 281, S8 B-9000

Gent ,Belgium

${ }^{5}$ International Ocean Discovery Program; Texas A\&M University; College Station Texas 77845, USA

${ }^{6}$ Department of Solid State Sciences; Ghent University; Krijgslaan 281 S1, B-9000 Gent ,Belgium

${ }^{7}$ Ifremer, LER AR, Station d'Arcachon, Quai du Cdt Silhouette; 33120 Arcachon, France

*Corresponding author : Kenneth Mertens, email address : kenneth.mertens@ifremer.fr

\begin{abstract}
:
The resting cysts of the benthic dinoflagellate Prorocentrum leve from a natural reservoir in GujanMestras (Gironde, France) were described in this study. The incubated urn-shaped cysts gave rise to cells of Prorocentrum leve. Morphological observations through light microscopy and scanning electron microscopy, particularly of the periflagellar platelets, combined with large subunit ribosomal DNA sequences obtained through single-cell analysis confirm their affinity to the species Prorocentrum leve. The cysts are characterized by a specific shape and the presence of an anterior plug. This is the first conclusive evidence for fossilizable resting stages within the Prorocentrales, one of the major orders within the Dinophyceae. Palynological treatments show that the cysts and endospores withstand hydrochloric and hydrofluoric acids. MicroFTIR analysis on single specimens suggests that the composition of the endospore is cellulosic and the cyst wall a more robust, non-cellulosic $\beta$-glucan. The spectra overall are similar to other published spectra of resting cysts from autotrophic, planktonic dinoflagellates.
\end{abstract}

Keywords : Prorocentrales, microFTIR, palynology, cellulosic, resting stage 
Abbreviations :

LSU large subunit

SSU smal subunit

SEM scanning electron microscopy

SSS sea-surface salinity

SST sea-surface temperature 


\section{INTRODUCTION}

The Prorocentrales form a large order of dinoflagellates that currently encompasses two genera: Prorocentrum (about 60 species; synonyms: Dinopyxis, Exuviaella, Postprorocentrum) and Mesoporos (three species; synonyms: Dinoporella, Porella, Porotheca; e.g., Hoppenrath et al. 2013). Prorocentrum species are almost exclusively marine, with only two freshwater species described (Croome and Tyler 1987). At present, 29 species of Prorocentrum are known to be benthic (Hoppenrath et al. 2013). At least nine benthic species and five planktonic species have been shown to produce okadaic acid (OA) and its analogues, dinophysistoxins (DTXs), borbotoxins and prorocentrolides or nonelucidated toxins (Lassus et al. 2016). Fossils are presently unknown for Prorocentrales (Fensome et al. 1993), and the position of Prorocentrum in molecular phylogenies is unstable (e.g., Janouškovec et al. 2016), which makes it difficult to understand the evolution of this group.

The life cycle of Prorocentrum resembles other dinoflagellates possessing a sexual cycle with formation of a planozygote, however the gametic nucleus is transmitted through a fertilization tube, as shown for the planktonic species Prorocentrum micans (Bhaud et al. 1988). Bhaud et al. (1988) did not observe formation of (sexual) resting cysts. However, resting cysts were previously described for the planktonic species Prorocentrum gracile and P. micans by Cannon (1993), and for the benthic species Prorocentrum lima by Faust 1993 and Faust et al. 1999, and for Prorocentrum foraminosum (= Prorocentrum marinum) by Faust $(1990,1993)$. It is unsure whether any of these findings are reliable records of fossilisable resting cysts, as previously expressed by Hoppenrath et al. (2013), following recommendations by the first author of this study. In addition, cysts produced from asexual division have been described for Prorocentrum micans by Braarud \& Rossavik (1951, p. 5-6) and for P. triestinum by Bursa (1959, p. 10). Another more recent paper illustrates what they 
consider to be (presumably asexual) temporary cysts of the benthic species Prorocentrum lima from Ghar El Melh Lagoon (Tunisia; Dhib et al. 2016).

The benthic dinoflagellate Prorocentrum leve was first described by Faust et al. (2008) from a mangrove island in Twin Cays (Belize). It has an atypical asexual production of long branching chains of adherent cells (Faust et al. 2008, as Prorocentrum levis [sic]). The correct ending for the epiteth, already used by Hoppenrath et al. (2013), is "e" because "levis", derived from Latin, was used as an adjective and needs to agree with the name to which it refers, which is neutral. Since its description, this species has been reported from Greek coastal waters (Aligizaki et al. 2009), the Adriatic Sea (Pistocchi et al. 2012, as $P$. cf. levis), and the Southeastern Bay of Biscay (David et al. 2014). Although P. leve was described as producing OA and dinophysis toxin-2 (DTX2) by Faust et al. (2008), this remains questionable because the only evidence is from a personal communication mentioned in Faust et al. (2008); toxicological analysis of European strains could not confirm these observations (Aligizaki et al. 2009, Pistocchi et al. 2012, David et al. 2014).

Here we present the first evidence of fossilizable resting cysts for Prorocentrum leve and describe their morphology. In addition, we document their phylogenetic position based on Large Subunit (LSU) ribosomal DNA (rDNA) sequences obtained through single-cell PCR. We also show that the cysts survive palynological treatment and analyze their geochemical composition using micro-Fourier transform infrared (FTIR) spectroscopy. The results show that the endospore is likely cellulosic but the outer cyst wall has a composition similar to other dinosporins from autotrophic, planktonic dinoflagellates.

This article is protected by copyright. All rights reserved. 


\section{MATERIAL AND METHODS}

Plankton and sediment sampling was done by M.R. and C.M. Plankton samples were studied by M.R., N.C., and E.N. Cyst incubation studies were performed by K.N.M. Scanning electron microscopy was done by K.N.M. and N.C. Molecular work was carried out by H.G. Palynological work was done by V.P. P.G., H.V. and K.B. carried out the geochemical analyses and spectral interpretation.

\section{Plankton sampling}

Plankton samples were obtained using plastic $1 \mathrm{~L}$ bottles that were filtered on a nylon mesh of $10 \mu \mathrm{m}$ on 15 April, 3 May and 10 May 2016. The samples were fixed using lugol and studied using an IX70 inverted light microscope.

\section{Germination experiments}

Sediment sampling was done using an Ekman grab on 15 and 19 April 2016 in a shallow natural reservoir used for oyster cleansing before commercialization (water depth 1.2-1.5 m). The small basin is located north of the community of Gujan-Mestras in the Gironde region of southwestern France $\left(44^{\circ} 38^{\prime} 11^{\prime \prime} \mathrm{N}, 1^{\circ} 04^{\prime} 00^{\prime \prime} \mathrm{W}\right)$. All samples were stored in plastic containers in a refrigerator at $4{ }^{\circ} \mathrm{C}$ in the dark. In situ sea-surface temperatures (SSTs) and in situ seasurface salinities (SSSs) were measured from April to July 2016 using a portable conductivity meter (WTW). SSTs varied between $14.8^{\circ} \mathrm{C}$ and $24.5^{\circ} \mathrm{C}$ and SSSs between 21.3 and 28.4.

About $0.5-1.0 \mathrm{~cm}^{3}$ of wet sediment was immersed in filtered seawater and rinsed through a Linker Industrietechnik (Kassel, Germany) $20 \mu \mathrm{m}$ metallic-meshed calibrated sieve using filtered seawater. From this residue, the cyst fraction was separated using the heavyliquid sodium polytungstate at a density of $1.3 \mathrm{~g} \cdot \mathrm{cm}^{-1}$ (Bolch 1997). Single cysts were then transferred to Nunclon $0.5 \mathrm{~mL}$ microwells subjected to an irradiance of $80-100 \mu \mathrm{mol}$ photons

This article is protected by copyright. All rights reserved. 
$\cdot \mathrm{m}^{-2} \cdot \mathrm{s}^{-1}$ and $12: 12$ light-dark photocycle at a temperature of $16^{\circ} \mathrm{C}$ and a salinity of 35 . Cysts were regularly checked for germination, and observations were performed under an Olympus (Tokyo, Japan) IX70 inverted light microscope. Cysts will cell contents and excised cysts and germinated motile cells were photographed and measured using an Olympus DP72 camera mounted on a BX41 microscope with 100x oil immersion objectives.

For scanning electron microscope (SEM) observations, cells were picked from the microwells and filtered using polycarbonate membrane filters (Millipore, Billerica, MA, USA; GTTP Isopore, $0.22 \mu \mathrm{m}$ pore size), and processed according to the methods described in Chomérat and Couté (2008). They were dehydrated in a graded series of ethanol baths (15\%-100\%), critical point dried, sputter coated with gold, and examined using a FEI Quanta $200 \mathrm{SEM}$ with an electron acceleration of 2.5 to $5 \mathrm{kV}$ at IFREMER (Brest, France).

The periflagellar platelets are important for identification of Prorocentrum species (e.g., Chomérat et al. 2010, Han et al. 2016). These platelets were identified based on the new system proposed by Hoppenrath et al. (2013).

\section{Study of cysts from surface sediment.}

Surface sediment samples from the same location as the germination experiment were processed using a standardized palynological preparation technique (e.g., Pospelova et al. 2010). All sediment samples were first desalted, dried, and analytically weighed. One tablet of exotic Lycopodium clavatum spores was added to each sample (e.g., Stockmarr 1971, Mertens et al. 2009, 2012) to determine dinoflagellate cyst absolute abundances. All samples were subsequently treated with room-temperature hydrochloric $(10 \% \mathrm{HCl})$ and hydrofluoric (25-48\% HF) acids to dissolve carbonates and silicates, respectively. Samples were rinsed

This article is protected by copyright. All rights reserved. 
twice with distilled water and sonicated for $\sim 30$ s prior to sieving that removed coarse $(>120$ $\mu \mathrm{m})$ and fine $(<15 \mu \mathrm{m})$ particles. In between each step, samples were centrifuged at $3600 \mathrm{rpm}$ for $6 \mathrm{~min}$. The residues were strew-mounted in glycerin jelly on glass slides for transmitted light microscopy examination.

For scanning electron microscope (SEM) observations, single cysts were picked from the residue filtered using polycarbonate membrane filters (Millipore, Billerica, MA, USA; GTTP Isopore, $0.22 \mu \mathrm{m}$ pore size), sputter coated with gold, and examined using a FEI Quanta 200 SEM with an electron acceleration of 2.5 to $5 \mathrm{kV}$ at IFREMER (Brest, France).

\section{Micro-FTIR spectroscopy of cysts}

For micro-FTIR spectroscopy, palynological residues were rinsed three times with organic solvents (methanol and dichloromethane) and MilliQ water to remove polar and apolar compounds. No sonication was used. Individual specimens were manually picked and placed on an Au-coated mirror, dried, and analyzed with a Bruker Hyperion 2000 microscope (15× objective) coupled to a Bruker Vertex 80v FTIR spectrometer at the Department of Solid State Sciences (Ghent University). The measurements were done in reflective mode through a $100 \times 100 \mu \mathrm{m}$ aperture size over $600-7000 \cdot \mathrm{cm}^{-1}$. Raw spectra from the endospore $(n=6)$, urn-shaped exospore with endospore $(n=1)$, cyst with plug $(n=2)$, cyst wall $(n=1)$, and cyst with plug and cell content $(n=3)$ were then subjected to background subtraction, atmospheric correction and rubberband baseline correction (5 iterations using polynomes), and smoothing.

This article is protected by copyright. All rights reserved. 
Single-cell PCR amplification and sequencing of cysts

Single cysts were isolated and washed three times with sterilized bi-distillate water and crushed by pressing down on the coverslip. They were used as template to amplify about 700 bp of the LSU rRNA gene (D1-D2 domains) using the primers D1R (forward, 5'ACCCGCTGAATTTAAGCATA-3') and D2C (5'-CCTTGGTCCGTTTCAAGA-3'; Scholin et al. 1994). A $50 \mu \mathrm{L}$ PCR cocktail containing $0.2 \mu \mathrm{M}$ forward and reverse primer, PCR buffer, $50 \mu \mathrm{M}$ dNTP, $1 \mathrm{U}$ of Taq DNA polymerase (Takara, Dalian, China) was subjected to 35 cycles using a Mastercycler PCR (Eppendorf, Hamburg, Germany). The thermal cycle procedure was $4 \mathrm{~min}$ at $94^{\circ} \mathrm{C}$, followed by 30 cycles of $1 \mathrm{~min}$ at $94^{\circ} \mathrm{C}, 1 \mathrm{~min}$ at $45^{\circ} \mathrm{C}, 1 \mathrm{~min}$ at $72^{\circ} \mathrm{C}$, and final extension of $7 \mathrm{~min}$ at $72^{\circ} \mathrm{C}$ with a Mastercycler (Eppendorf, Hamburg, Germany). PCR products were sequenced directly in both directions using the ABI Big-Dye dye-terminator technique (Applied Biosystems, Foster City, CA, USA), according to the manufacturer's recommendations. New sequences were deposited in GenBank with accession numbers from MF479742 to MF479743.

\section{Sequence alignments and phylogenetic analyses}

Newly obtained partial LSU rRNA gene sequences were incorporated into those of Prorocentrum available in GenBank based on studies by Luo et al. (2017). Sequences were aligned using MAFFT v7.110 (Katoh and Standley 2013) online program (http://mafft.cbrc.jp/alignment/server/; Carroll et al. 2007). Alignments were manually checked with BioEdit v. 7.0.5 (Hall 1999). For Bayesian inference (BI), the program jModelTest (Posada 2008) was used to select the most appropriate model of molecular evolution with Akaike Information Criterion (AIC). Bayesian reconstruction of the data matrix was performed using MrBayes 3.2 (Ronquist and Huelsenbeck 2003) with the bestfitting substitution model (TIM1+G). Four Markov chain Monte Carlo (MCMC) chains ran

This article is protected by copyright. All rights reserved. 
for 2,000,000 generations, sampling every 100 generations. Convergence diagnostics were graphically estimated using AWTY (http://ceb.scs.fsu.edu/awty; Nylander et al. 2008) and the first $10 \%$ of burn-in trees were discarded. A majority rule consensus tree was created in order to examine the posterior probabilities of each clade. Maximum likelihood (ML) analyses were conducted with RaxML v7.2.6 (Stamatakis 2006) on the T-REX web server (Boc et al. 2012) using the model GTR+G. Node support was assessed with 1000 bootstrap replicates.

\section{RESULTS}

Study of plankton samples

Study of plankton samples revealed the presence of three epibenthic Prorocentrum species: P. cf. fukuyoi, P. leve and P. lima and one planktonic Prorocentrum: P. micans. P. leve was present in the samples taken on 15th April, 3th May, and 10th May, 2016.

\section{Germination experiment}

One incubation experiment took place on April 25 $5^{\text {th }}, 2016$ at LER BO, Concarneau. Motile cells, here assigned to Prorocentrum leve (Fig. 1), emerged from previously undescribed cysts isolated from the studied surface sediments. Some of these cysts had a remarkable outer exospore consisting of an urn-shaped exospore enclosed by a plug on the anterior side, enclosing the endospore and cell contents. In other cysts this outer exospore was missing, and only the endospore was present. After one or two days of incubation, motile cells germinated from the cysts and started division.

This article is protected by copyright. All rights reserved. 
Study of palynological treated surface sediment

The urn-shaped cysts with plug were observed in the studied microscope slides after palynological treatment (Fig. 2, H-I). Cysts without this exospore and only the endospore were also present (Figs. 3, E-F; 4, G-I). In addition, what are considered plates of the endospore were also observed.

Species description

Division DINOFLAGELLATA (Bütschli 1885) Fensome et al. 1993

Class DINOPHYCEAE Pascher 1914

Subclass PROROCENTROPHYCIDAE Fensome et al. 1993

Order PROROCENTRALES Lemmermann 1910

Family Prorocentraceae Stein 1883

Genus Prorocentrum Ehrenberg 1834

Prorocentrum leve M.A. Faust, M.W. Vandersea, S.R. Kibler, P.A. Tester \& R.W. Litaker 2008

(Figs. 1-4)

Gene sequence. The 28S rDNA gene sequences of the cell—GenBank Accession No. MF479742-MF479743 (28S).

Description. Description of motile cell of Prorocentrum leve. The excysted motile cells of $P$. leve are oval, with a shallow cusp at the anterior end (Fig. 1, A-B). A central pyrenoid and golden-brown plastids are present. The nucleus is located posteriorly. The thecal plates are smooth, bearing 214-298 round pores $(n=2)$, which are more concentrated on the periphery, adjacent to the intercalary band. The center lacked pores. There were small pores and somewhat larger pores. Pore diameter varied between 0.17 and $0.21 \mu \mathrm{m}(\mathrm{n}=3)$. The periflagellar area with eight platelets was moderately excavated, V-shaped, with a large,

This article is protected by copyright. All rights reserved. 
oblong flagellar pore and a small accessory pore. The intercalary band is smooth. The wall is thick. Cells grew in culture by asexual multiplication forming long chains of cells within a hyaline envelope (Fig. 1F).

Description of cysts of Prorocentrum leve. The cysts are transparent and flattened laterally. There are two layers. A thin outer urn-shaped exospore with a closely attached plug. This urn-shaped exospore is smooth, consists of two halves connected by a suture, does not show pores and has an opening at the anterior side. The plug is irregular in outline and does not show tabulation. Sometimes the plug was observed detached from the urn-shaped exospore (Fig. 3C). The plug color is brownish after palynological treatment (Fig. 2, H-I). There is a thick endospore under the outer exospore that is birefringent under crossed polars. When the exospore was missing, the morphology of the endospore could not be distinguished from the theca (Figs. 3E; 4). For living cysts, inside the endospore golden brown pigments and the central pyrenoid could be observed; often also Brownian motion. After palynological treatment, the chloroplasts and pyrenoid lost their original color (Figs. 2H; 4G). Some cysts isolated from the sediment had the characteristic urn-shaped exospore and the endospore, but others only had the endospore. Both types germinated and gave rise to a typical $P$. leve motile stage, and the urn-shaped exospore and endospore were left in the microwells. The archeopyle is a split along the sagittal suture (Fig. 2F).

Dimensions. Thecate cells: length, 36.2 (40.8) $46.6 \mu \mathrm{m}(\mathrm{n}=12)$; width, 32.7 (35.9) $42.0 \mu \mathrm{m}$ $(n=12)$.

Cysts that included plug: length (including plug), 46.2 (52.4) $58.6 \mu \mathrm{m}(\mathrm{n}=8)$, and width, 35.5 (43.9) $46.1 \mu \mathrm{m}(\mathrm{n}=8)$.

Comments. The exospore and endospore withstand palynological treatment.

This article is protected by copyright. All rights reserved. 
Geochemical composition of Prorocentrum leve cysts

Several different aspects of Prorocentrum leve cysts were investigated to provide information regarding their geochemical composition, including the endospore, urn-shaped exospore with the endospore, the outer exospore with and without the plug (hereafter called the cyst wall), and the cyst with cell content (Fig. 6). Band assignment were based on published literature (e.g., Colthup 1990, Brandenburg and Seydel 1996, Pretsch et al. 2009, Versteegh et al. 2012, Bogus et al. 2014, Mertens et al. 2015). Due to the complexity of the spectra it was not possible to definitively assign each of the IR bands. The broadness of many absorptions suggests that overlapping bands are close in frequency and further studies are needed to deconvolve the individual spectra, which would provide additional structural information. All spectra demonstrate broad absorptions centered $\sim 3300 \cdot \mathrm{cm}^{-1}(\mathrm{OH}$ stretching $)$ and the area between $3000-2775 \cdot \mathrm{cm}^{-1}$ that reflects aliphatic C-H stretching. The latter can also be associated with methyl group bending at $1420 \cdot \mathrm{cm}^{-1}$ and $1360 \cdot \mathrm{cm}^{-1}$ (not indicated in Fig. 6).

The IR region between $1800-800 \cdot \mathrm{cm}^{-1}$ was the most distinct between the different specimens. The endospore specimens (M3S1, M3S2, M3S13, M3S16, M3S25 and M3S28; Fig. 6A) exhibit absorptions at $1640 \cdot \mathrm{cm}^{-1}(\mathrm{C}=\mathrm{O}$ stretching), which was sometimes a shoulder, and $1600 \cdot \mathrm{cm}^{-1}$ for $\mathrm{C}=\mathrm{C}$ stretching and possibly $\mathrm{COO}$ - stretching. These absorptions were also present, at varying relative strengths, in specimens containing the cyst wall and endospore (M3S8; Fig. 6B), cyst with plug (M3S14, M3S27; Fig. 6C), and cyst wall (M3S21; Fig. 6D). The absorption at $1640 \cdot \mathrm{cm}^{-1}$ was also present in the cysts with cell content (M3S15, M3S20, M3S26; Fig. 6E), but the presence of an absorption at $1550 \cdot \mathrm{cm}^{-1}$, characteristic of protein amide II bands and unique to these specimens, suggest that the absorption at $1640 \mathrm{~cm}^{-1}$ is part of a protein amide $\mathrm{I}(\mathrm{C}=\mathrm{O})$ band. These specimens' spectra also exhibit absorptions at $1735 \cdot \mathrm{cm}^{-1}(\mathrm{C}=\mathrm{O}$ stretching of aliphatic esters). The cyst wall spectrum (Fig. 6D) also shows an absorption at $1735 \cdot \mathrm{cm}^{-1}$ although it is quite small. Only

This article is protected by copyright. All rights reserved. 
the cysts containing cell content exhibit an absorption at $1250 \cdot \mathrm{cm}^{-1}$ characteristic of proteinaceous material and nucleic acids. Absorptions from 1160-950 represent C-O stretching and the deformation vibrations of sugar rings at $1155 \cdot \mathrm{cm}^{-1}(\mathrm{C}-\mathrm{O}-\mathrm{C}$ asymmetric vibration) and $1105 \cdot \mathrm{cm}^{-1}$ (glucose ring stretching). Most specimens show the same series of C-O stretching absorptions $\left(1060 \cdot \mathrm{cm}^{-1}, 1030 \cdot \mathrm{cm}^{-1}, 1005 \cdot \mathrm{cm}^{-1}\right)$ where the peak at 1030 . $\mathrm{cm}^{-1}$ is the strongest; however, the cysts with cell content show absorptions at $1018 \cdot \mathrm{cm}^{-1}$ and $1005 \cdot \mathrm{cm}^{-1}$ with the latter as the strongest absorption. All spectra demonstrate multiple absorptions below $950 \cdot \mathrm{cm}^{-1}$ demonstrating deformations of O-C-H, C-O-H and C-C-H, as well as absorptions at $901 \cdot \mathrm{cm}^{-1}$ (Fig. 6, A-D) and $895 \cdot \mathrm{cm}^{-1}$ (Fig. 6E) for the B-glycosidic bond.

\section{Phylogenetic position of Prorocentrum leve based on LSU rDNA}

Prorocentrum leve from Gujan-Mestras share identical LSU sequences and only differ from strains from the Mediterranean Sea and Belize at 1 or 12 positions $(99.9 \%$ and $98.2 \%$ similarity). Maximum likelihood (ML) and Bayesian inference (BI) generated trees with identical topologies. Prorocentrum was divided into two clades one comprising mainly epibenthic species and another comprising mainly planktonic species (Fig. 7). Prorocentrum leve from Gujan-Mestras form a well-resolved clade together with those from the Mediterranean Sea and Belize with maximal support (ML bootstrap support: 100, BI posterior probability: 1.0), and is nested within the clade comprising mainly epibenthic species (Fig. 7). Prorocentrum leve forms a sister clade of $P$. foraminosum with a low support (100/ 0.7) and again is a sister clade of P. concavum with maximal support (Fig. 7).

This article is protected by copyright. All rights reserved. 


\section{DISCUSSION}

Identification of the species as Prorocentrum leve and phylogenetic comparison

Our studied specimens agree well with the Prorocentrum leve specimens described in previous studies (Table 1). Regarding differences to other Prorocentrum species, we refer to Hoppenrath et al. (2013). The phylogenetic tree (Fig. 7) shows that $P$. leve from GujanMestras is close to other strains identified as $P$. leve, and that $P$. leve is closest to $P$. concavum and $P$. foraminosum, as previously suggested by Hoppenrath et al. (2013), David et al. (2014), and Luo et al. (2017).

\section{Comparison of the cyst to other cyst-based taxa}

To the best of our knowledge, the characteristic rounded urn-shaped cysts described here have never been observed before. They bear some superficial resemblance to fossil dinoflagellate cyst-defined species (known only from the Jurassic) belonging to the genus Nannoceratopsis of the order Nannoceratopsiales, in that they also have two large plates separated by a sagittal suture (e.g., Piel and Evitt 1980). However, as already pointed out by Piel and Evitt (1980), Nannoceratopsis contrasts fundamentally with the Prorocentrales in having an epicyst composed of several plates in addition to a cingulum and sulcus, and is considered an intermediate between Peridiniales and Dinophysales (e.g., Janouškovec et al. 2016). Albeit superficial, the similarity between cyst of Prorocentrum leve and Nannoceratopsis is interesting because it provides some evidence for a common ancestor between Prorocentrales, Nannoceratopsiales and Dinophysales.

This article is protected by copyright. All rights reserved. 
Are these really resting cysts?

There are several reasons why we consider the Prorocentrum leve cysts described here to be resting cysts, primarily that they (1) were isolated from sediment using the sodium polytungstate method (Bolch 1997), (2) were non-motile and bore no flagella, (3) exhibited Brownian motion and (4) germinated after only a few days of incubation. Additionally, there were no divisions observed within the cyst, so they are not division cysts. Finally, the cysts withstand palynological treatment, indicating some resistance to mechanical and chemical degradation, which are properties associated with some resting cysts (e.g., Hopkins and McCarthy 2002). If they are indeed resting cysts, then they should be made of dinosporin and could be similar to other analyzed dinoflagellate cysts. In fact, the $P$. leve cysts without cell content (Fig. 6, A-D) have a similar composition to other published autotrophic spectra (e.g., Versteegh et al. 2012, Bogus et al. 2014, Mertens et al. 2015, Gurdebeke et al. accepted), suggesting they are carbohydrate-based. This is particularly evident from the series of characteristic polysaccharide absorptions between $1160-950 \cdot \mathrm{cm}^{-1}$ and the peak at $901 \cdot \mathrm{cm}^{-1}$ (ß-glycosidic bond; Pandey 1999, Kačuráková and Wilson 2001). Thus, the cyst wall composition seems to be broadly consistent (i.e., carbohydrate-based) regardless of whether the endospore is measured with the cyst wall (Fig. 6, A-B, D). The brownish colored plug is possibly cellulosic, because those spectra with a pronounced plug (Fig. 6C) more closely resemble the cellulose spectrum (Pandey 1999). In addition, half of the endospore spectra (M3S13, M3S25 and M3S28) are similar to cellulose, but the other three (M3S1, M3S2 and M3S16) exhibit a strong absorption at $1600 \cdot \mathrm{cm}^{-1}$ more akin to the combined endospore and cyst wall spectrum (Fig. 6B) and cyst wall only (Fig. 6D). This could suggest that even when the endospore appears visually to lack the outer cyst wall, residual material may remain and produce a composite spectrum. We suggest that the endospore is also cellulosic. However, the outer cyst wall is probably a non-cellulosic $\beta$-glucan, which would be consistent with the 
cyst walls from other autotrophic dinoflagellates. Non-cellulosic $\beta$-glucans, such as mannan, are common and well-documented components in plant (e.g., Kačuráková and Wilson 2001, Burton and Fincher 2009) and algal cell walls (e.g., Frei and Preston 1964, Stone 2009), including the dinoflagellate Peridinium westii (Nevo and Sharon 1969). The Prorocentrum leve cyst wall has a more prominent peak at $1600 \cdot \mathrm{cm}^{-1}$, similar to Spiniferites species (Gurdebeke et al. accepted), Tuberculodinium vancampoae (Bogus et al. 2014) and Pyrodinium bahamense (Mertens et al. 2015). This, combined with the small peak at 1735 . $\mathrm{cm}^{-1}$, could indicate a more robust chemical composition, relative to the endospore, containing more ester functional groups. Measurement of cysts with cell content (Fig. 6E) show additional peaks (i.e., $1550 \cdot \mathrm{cm}^{-1}, 1250 \cdot \mathrm{cm}^{-1}$, and $1018 \cdot \mathrm{cm}^{-1}$ ) and/or shifted dominant absorptions (from $1030 \cdot \mathrm{cm}^{-1}$ to $1005 \cdot \mathrm{cm}^{-1}$ ) in the raw spectra that obscures the cyst wall composition. This demonstrates that extreme care is needed to ensure that cysts are free from proteinaceous material before chemical composition analysis. Thus, based on the cyst wall geochemistry, it seems plausible that these cysts are resting stages and given the fact that the known life cycle of Prorocentrales includes a sexual phase (Bhaud et al. 1988), it is possible that the resting cysts are produced from a sexual stage, but this aspect will require further study.

Our findings confirm the presence of resting cysts within the Prorocentrales, as previously suggested by Faust (1990, 1993) and Faust et al. (1999). Spherical resting cysts were previously described only for the benthic species Prorocentrum lima (Faust, 1993, Faust et al. 1999) and Prorocentrum foraminosum by Faust (1990, 1993), and these do not have a similar morphology to the urn-shaped cysts of Prorocentrum leve described here. Although these observations are incomplete, they are probably reliable. Cysts produced from asexual division described for Prorocentrum micans by Braarud and Rossavik (1951) and for $P$. triestinum by Bursa (1959) clearly differ in not having an endospore. However, temporary

This article is protected by copyright. All rights reserved. 
cysts of the benthic species Prorocentrum lima from Ghar El Melh Lagoon (Tunisia) despicted by Dhib et al. (2016) do resemble the type 2 cysts (with endospore only) described here. Further studies are required regarding these other cyst taxa, as these species lack important information, such as the archeopyle, and to confirm whether these are really fossilizable resting cysts It is also interesting to speculate that the cellulosic plug of the urnshaped cysts could serve as an attachment structure (e.g., to macroalgae or sand grains), however, we were unable to verify this. In addition, this study corroborates evidence for resting cysts produced by benthic dinoflagellates, as previously shown for Bysmatrum subsalsum by Limoges et al. (2015). It is of interest to note that both Limoges et al. (2015) and this study found cysts at very shallow water depths $(<1.5 \mathrm{~m})$, which could partly explain why these cysts have not been described before.

\section{CONCLUSIONS}

Our incubation experiments established the cyst-theca relationship for Prorocentrum leve, a species that was identified through SEM and LSU rDNA sequencing. The cysts and endospores withstand palynological treatment. Micro-FTIR analyses of the cysts indicate that they are carbohydrate-based and overall are similar to other published spectra of resting cysts from autotrophic, planktonic dinoflagellates. The discovery of resting cysts within the Prorocentrales is important because it can help us to understand their evolution, dispersal strategies, and life cycle.

\section{ACKNOWLEDGEMENTS}

Rob Fensome, Graham Williams and Jim Riding are thanked for useful discussions regarding the cyst morphology. N. Gayet is acknowledged for critical-point drying of the samples for SEM. This research was partly supported by the Natural Sciences and Engineering Research

This article is protected by copyright. All rights reserved. 
Council of Canada (NSERC) through a Discovery grant to VP. The Hercules Foundation (Flanders) is gratefully acknowledged for financial support (FT-IMAGER project AUGE/13/16).

\section{REFERENCES}

Aligizaki, K., Nikolaidis, G., Katikou, P., Baxevanis, A. D. \& Abatzopoulos, T. J. 2009. Potentially toxic epiphytic Prorocentrum (Dinophyceae) species in Greek coastal waters. Harmful Algae 8:299-311.

Bhaud, Y., Soyer-Gobillard, M. O. \& Salmon, J. M. 1988. Transmission of gametic nuclei through a fertilization tube during mating in a primitive dinoflagelate, Prorocentrum micans Ehr. J. Cell Sci. 89:197-206.

Boc, A., Diallo, A.B., Makarenkov, V. 2012. T-REX: a web server for inferring, validating and visualizing phylogenetic trees and networks. Nucleic Acids Res. 40:W573-9.

Bogus, K., Mertens, K. N., Lauwaert, J., Harding, I. C., Vrielinck, H., Zonneveld, K. A. F. \& Versteegh, G. J. M. 2014. Differences in the chemical composition of organic-walled dinoflagellate resting cysts from phototrophic and heterotrophic dinoflagellates. J. Phycol. 50:254-266.

Bolch, C. J. S. 1997. The use of polytungstate for the separation and concentration of living dinoflagellate cysts from marine sediments. Phycologia 37:472-478.

This article is protected by copyright. All rights reserved. 
Braarud, T. \& Rossavik, E. 1951. Observations of the marine dinoflagellate Prorocentrum micans Ehrenb. in culture. Avhandl. Norske Videnskaps Acad. Oslo. I. Mat. Naturv. Kl. 1:318.

Brandenburg, K. \& Seydel, U. 1996. Fourier transform infrared spectroscopy of cell surface polysaccharides. In Mantsch H.H. \& Chapman D. [Eds.] Infrared Spectroscopy of Biomolecules, Wiley, Chichester, UK. pp. 203-278.

Bursa, A. 1959. The genus Prorocentrum Ehrenberg. Morphodynamics, protoplasmic structures and taxonomy. Canad. J. Bot. 37:1-31.

Burton, R. A. \& Fincher, G. B. 2009. (1,3; 1,4)- $\beta$-D-glucans in cell walls of the Poacea, lower plants and fungi: a tale of two linkages. Mol. Plant. 2:873-882.

Carroll, H., Beckstead, W., O'Connor, T., Ebbert, M., Clement, M., Snell, Q., McClellan, D., 2007. DNA reference alignment benchmarks based on tertiary structure of encoded proteins. Bioinformatics 23:2648-2649.

Chomérat, N. \& Couté, A. 2008. Protoperidinium bolmonense sp. nov. (Peridiniales, Dinophyceae), a small dinoflagellate from a brackish hypereutrophic lagoon (south of France). Phycologia 47:392-403.

Chomérat, N., Sellos, D. Y., Zentz, F., Nézan, E. 2010. Morphology and molecular phylogeny of Prorocentrum consutum sp. nov. (Dinophyceae), a new benthic dinoflagellate from South Brittany (Northwestern France). J. Phycol. 46:183-194.

This article is protected by copyright. All rights reserved. 
Colthup, N. B., Daly, L. H. \& Wiberly, S. E. 1990. Introduction to Infrared and Raman

Spectroscopy. Academic Press Limited, London, UK. 282 pp.

Croome R.L. \& Tyler P.A. 1987. Prorocentrum playfairi and Prorocentrum foveolata, two new dinoflagellates from Australian freshwaters. Eur. J. Phycology 22:67-75.

David, H., Laza-Martinez, A., García-Extebarria, K., Riobó, P. \& Orive, E. 2014.

Characterisation of Prorocentrum elegans and Prorocentrum levis (Dinophyseae) from the southeastern Bay of Biscay by morphology and molecular phylogeny. J. Phycol. 50:718-726.

Dhib, A., Fertouna-Bellakhal, M., Turki, S. \& Aleya, L. 2016. Driving factors of dinoflagellate cyst distribution in surface sediments of a Mediterranean lagoon with limited access to the sea. Mar. Poll. Bull. 112:303-312.

Faust, M. A. 1990. Cysts of Prorocentrum marinum (Dinophyceae) in floating detritus at Twin Cays, Belize mangrove habitats. In Granéli, E. [Ed.] Toxic Marine Phytoplankton. Elsevier Science Publishing Co., Inc., New York, pp. 138-143.

Faust, M.A. 1993. Sexuality in a toxic dinoflagellate, Prorocentrum lima. In Smayda, T.J. \& Shimizu, Y. [Eds]. Toxic phytoplankton blooms in the Sea. Elsevier Science Publishing Co., Inc., New York, pp. 121-126.

Faust, M. A., Larsen, J. \& Moestrup, Ø. 1999. ICES identification leaflets for plankton. Leaflet no. 184. Potentially toxic phytoplankton. 3. Genus Prorocentrum (Dinophyceae). In International Council for the Exploitation of the Sea, Copenhagen, Denmark, 24 pp.

This article is protected by copyright. All rights reserved. 
Faust, M. A., Vandersea, M. W., Kibler, S. R., Tester, P. A. \& Litaker, R. W. 2008.

Prorocentrum levis, a new benthic species (Dinophyceae) from a mangrove island, Twin Cays, Belize. J. Phycol. 44:232-240.

Fensome, R. A., Taylor, F. J. R., Norris, G., Sarjeant, W. A. S., Wharton, D. I. \& Williams, G. L. 1993. A Classification of Living and Fossil Dinoflagellates. Micropaleontology, Special Publication 7. Sheridan Press, Hanover, PA, USA, 351 pp.

Frei, E. \& Preston, R. D. 1964. Non-cellulosic structural polysaccharides in algal cell walls I. Xylan in siphoneous green algae. P. Roy. Soc. Lond. B Bio. 160:293-313.

Gurdebeke, P.R., Mertens, K.N., Bogus, K., Marret, F., Chomérat, N., Vrielinck, H., Louwye, S. (accepted). Taxonomic reinvestigation and geochemical characterization of Reid's (1974) species of Spiniferites from holotype and topotype material. Palynology

Hall, T. A. 1999. BioEdit: a user-friendly biological sequence alignment editor and analysis program for Windows 95/98/NT. Nucleic Acids Symp. Ser. 41:95-98.

Han, M. S., Wang, P., Kim, J.H., Cho, S. Y., Park, B.S., Kim, J. H., Katano, T., Kim, B. H. 2016. Morphological and molecular phylogenetic position of Prorocentrum micans sensu stricto and description of Prorocentrum koreanum sp. nov. from Southern Coastal Waters in Korea and Japan. Protist 167:32-50.

This article is protected by copyright. All rights reserved. 
Hopkins, J. A. \& McCarthy, F. M. G. 2002. Post-depositional palynomorph degradation in Quaternary shelf sediments: a laboratory experiment studying the effects of progressive oxidation. Palynology 26:167-184.

Hoppenrath, M., Chomérat, N., Horiguchi, T., Schweikert, M., Nagahama, Y., Murray, S. 2013. Taxonomy and phylogeny of the benthic Prorocentrum species (Dinophyceae)—A proposal and review. Harmful Algae 27:1-28.

Janouškovec, J., Gavelis, G. S., Burki, F., Dinh, D., Bachvaroff, T. R., Gornik, S. G., Bright, K. J., Imanian, B., Strom, S. L., Delwiche, C. F., Waller, R. F., Fensome, R. A., Leander, B. S., Rohwer, F.L. \& Saldarriaga, J. F. 2016. Major transitions in dinoflagellate evolution unveiled by phylotranscriptomics. Proc. Natl. Acad. Sci. USA 114:E171-E180.

Kačuráková M. \& Wilson R.H. 2001. Developments in mid-infrared FT-IR spectroscopy of selected carbohydrates. Carbohydr. Polym. 44:291-303.

Katoh, K. \& Standley, D.M. 2013. MAFFT Multiple Sequence Alignment Software Version 7: Improvements in Performance and Usability. Mol. Biol. Evol. 30:772-780.

Lassus, P., Chomérat, N., Hess, P. \& Nézan, E. 2016. Toxic and harmful microalgae of the World Ocean. IOC Manuals and Guides 68, 523 pp.

Limoges, A., Mertens, K. N., Ruíz-Fernández, A. C. \& de Vernal, A. 2015. First report of fossilized cysts produced by the benthic Bysmatrum subsalsum (Dinophyceae) from a shallow Mexican lagoon in the Gulf of Mexico. J. Phycol. 51:211-215.

This article is protected by copyright. All rights reserved. 
Luo, Z., Zhang, H., Krock, B., Lu, S., Yang, W., Gu, H. 2017. Morphology, molecular phylogeny and okadaic acid production of epibenthic Prorocentrum (Dinophyceae) species from the northern South China Sea. Algal Research 22:14-30.

Mertens, K.N., Verhoeven, K., Verleye, T., Louwye, S., Amorim, A., Ribeiro, S., Deaf, A. S. et al. 2009. Determining the absolute abundance of dinoflagellate cysts in recent marine sediments: The Lycopodium marker-grain method put to the test. Rev. Palaeobot. Palynol. $157: 238-252$.

Mertens, K. N., Price, A. M. \& Pospelova, V. 2012. Determining the absolute abundance of dinoflagellate cysts in recent marine sediments II: Further tests of the Lycopodium markergrain method. Rev. Palaeobot. Palynol. 184:74-81.

Mertens, K. N., Wolny, J., Carbonell-Moore, C., Bogus, K., Ellegaard, M., Limoges, A., de Vernal, A., Gurdebeke, P., Omura, T., al-Muftah, A. \& Matsuoka, K. 2015. Taxonomic reexamination of the toxic armored dinoflagellate Pyrodinium bahamense Plate 1906: can morphology or LSU sequencing separate $P$. bahamense var. compressum from var. bahamense? Harmful Algae 41:1-24.

Nevo, Z. \& Sharon, N. 1969. The cell wall of Peridinium westii, a non-cellulosic glucan. Biochim. Biophys. Acta 173:161-175.

Nylander, J.A.A., Wilgenbusch, J.C., Warren, D.L. \& Swofford, D.L. 2008. AWTY (are we there yet?): a system for graphical exploration of MCMC convergence in Bayesian phylogenetics. Bioinformatics 24:581-3.

This article is protected by copyright. All rights reserved. 
Pandey, K. K. 1999. A study of chemical structure of soft and hardwood and wood polymers by FTIR spectroscopy. J. Appl. Polym. Sci. 71:1969-75.

Piel, K. M. \& Evitt, W. M. 1980. Paratabulation in the Jurassic dinoflagellate genus Nannoceratopsis and a comparison with modern taxa. Palynology 4:79-104.

Pistocchi, R., Guerrini, F., Pezzolesi, L., Riccardi, M., Vanucci, S., Ciminiello, P., Dell'Aversano, C., Furino, M., Fattorusso, E., Tartaglione, L., Milandri, A., Pompei, M., Cangini, M., Pigozzi, S. \& Riccardi, E. 2012. Toxin levels and profiles in microalgae from the North-Western Adriatic Sea - 15 years of studies on cultured species. Mar. Drugs 10:140-62.

Posada, D. 2008. jModelTest: phylogenetic model averaging. Mol. Biol. Evol. 25:1253-1256.

Pospelova V., Esenkulova S., Johannessen S.C., O'Brien M. C. \& Macdonald R.W. 2010. Organic-walled dinoflagellate cyst production, composition and flux from 1996 to 1998 in the central Strait of Georgia (BC, Canada): a sediment trap study. Mar. Micropaleontol. $75: 17-37$

Pretsch, E., Bühlmann, P. \& Badertscher, M. 2009. Structure Determination of Organic Compounds. Springer-Verlag, Berlin Heidelberg, pp. 444.

Ronquist, F. \& Huelsenbeck, J. P. 2003. MRBAYES 3: Bayesian phylogenetic inference under mixed models. Bioinformatics 19:1572-4.

This article is protected by copyright. All rights reserved. 
Scholin, C. A., Herzog, M., Sogin, M. \& Anderson, D. M. 1994. Identification of group and strain-specific genetic markers for globally distributed Alexandrium (Dinophyceae). II. Sequence analysis of a fragment of the LSU rRNA gene. J. Phycol. 30, 999-1011.

Stamatakis, A. 2006. RAxML-VI-HPC: maximum likelihood-based phylogenetic analyses with thousands of taxa and mixed models. Bioinformatics 22:2688-2690.

Stockmarr J. 1971. Tablets with spores used in absolute pollen analysis. Pollen Spores $13: 615-21$

Stone, B. A. 2009. Chemistry of $\beta$-glucans. In Bacic, A., Fincher, G. B. \& Stone, B. A. [Eds.] Chemistry, biochemistry, and biology of (1-3)- $\beta$-glucans and related polysaccharides. Academic Press, Elsevier Inc., London, pp. 5-46.

Versteegh, G. J. M., Blokker, P., Bogus, K., Harding, I. C., Lewis, J., Oltmanns, S., Rochon, A. \& Zonneveld, K. 2012. Infrared spectroscopy, flash pyrolysis, thermally assisted hydrolysis and methylation (THM) in the presence of tetramethylammonium hydroxide (TMAH) of cultured and sediment-derived Lingulodinium polyedrum (Dinoflagellata) cyst walls. Org. Geochem. 43:92-102.

This article is protected by copyright. All rights reserved. 
Table 1: measurements of cells of Prorocentrum leve as reported in previous studies and this study.

\begin{tabular}{|l|cccc|}
\hline & \multicolumn{3}{|c|}{ Cell width } & Pores per \\
& Cell length $(\mu \mathrm{m})$ & $(\mu \mathrm{m})$ & valve & Pore diameter $(\mu \mathrm{m})$ \\
\hline Faust et al. 2008 & $40-44$ & $37-40$ & $221-238$ & $0.13-0.19$ \\
Aligizaki et al. 2009 & $38.1-48.6$ & $33.3-36.9$ & & NA \\
& $(\mathrm{n}=40)$ & $(\mathrm{n}=40)$ & & \\
& $37.41-50.76$ & $30.20-42.20$ & $211-222$ & $0.12-0.19$ \\
David et al. 2014 & $(\mathrm{n}=20)$ & $(\mathrm{n}=20)$ & $(\mathrm{n}=7)$ & $(\mathrm{n}=53)$ \\
& $36.2-46.6$ & $32.7-42.0$ & $214-298$ & $0.17-0.21$ \\
& $(\mathrm{n}=12)$ & $(\mathrm{n}=12)$ & $(\mathrm{n}=2)$ & $(\mathrm{n}=3)$ \\
\hline
\end{tabular}

Figure captions

FIG. 1. Light micrographs and scanning electron micrograph of cells of Prorocentrum leve.

(A-B) Light micrographs of two cells observed in lugol fixed plankton samples showing general shape of the cell and golden-brown chloroplasts. (C-E). Scanning electron micrographs of a single cell of $P$. leve germinated from urn-shaped cysts show in Fig. 2. (E) Focus on periflagellar area showing the 8 platelets (' 1 '-' 8 '), accessory pore 'a' and flagellar pore ' $\mathrm{f}$ '. (F) Chains of adherent cells formed in strain of $P$. leve. All scale bars $=10 \mu \mathrm{m}$, except in $(E)=2 \mu \mathrm{m}$.

This article is protected by copyright. All rights reserved. 
FIG. 2. Light micrographs of cysts of Prorocentrum leve. (A-C) High to mid focus of living urn-shaped cyst with plug isolated from surface sediment for incubation. (D) Urn-shaped cyst with plug before germination. (E-F) Same urn-shaped cyst with plug as in (D) after germination, (F) shows side view with opened archeopyle shown by arrow. (G) Urn-shaped cyst with plug using for single-cell PCR. (H) Urn-shaped cyst after palynological treatment, showing loss of pigment color in both chloroplasts and pyrenoid and brown color of plug. (I) Side view of urn-shaped cyst with plug after palynological treatment. All scale bars $=10 \mu \mathrm{m}$.

FIG. 3. Scanning electron micrograph of cysts and endospores of Prorocentrum leve extracted from palynological sample. (A-B) Different orientations of single urn-shaped cyst with plug, (A) left plate, (B) Apical view, with detail of plug. (C) Urn-shaped cyst where plug was detached. (D) Urn-shaped cyst where one plate is missing, showing detail of plug and endospore. (E) Left plate of endospore. (F) Internal view of left plate of endospore. All scale bars $=10 \mu \mathrm{m}$.

FIG. 4. Light micrograph of cysts that lacked urn-shaped exospore and plug. (A-C) Different stages of cyst without urn-shaped exospore where cell contents are contracting and are getting ready for excystment. (D-F). Cyst after germination, (F) shows blue fluorescent of calcofluor stained endospore. (G) Cyst after palynological treatment. (H-I). Left plate of endospore after palynological treatment (mid to low focus). All scale bars $=10 \mu \mathrm{m}$.

FIG. 5. Scheme of resting cysts of Prorocentrum leve, with indication of plug (P), exospore (Exo) and endospore (Endo).

This article is protected by copyright. All rights reserved. 
FIG. 6. Micro-FTIR spectra for Prorocentrum leve cysts. (A) Endospore only. (B) Urn-shaped outer exospore with endospore. (C) Cyst with plug. (D) Urn-shaped outer exospore only. (E) Cyst with plug and cell content. Inverted microscope images of some of the measured specimens are also shown.

FIG. 7. Maximum-likelihood (ML) tree of Prorocentrum inferred from 28S rDNA sequences with Adenoides eludens as the outgroup. ML bootstrap support values (ML) over $50 \%$ and Bayesian posterior probabilities (PP) over 0.90 are shown at the nodes (ML/PP). * indicates maximal support (ML:100, PP: 1.0). The scale bar represents inferred evolutionary distance in changes/site. New sequences indicated in bold.

This article is protected by copyright. All rights reserved. 


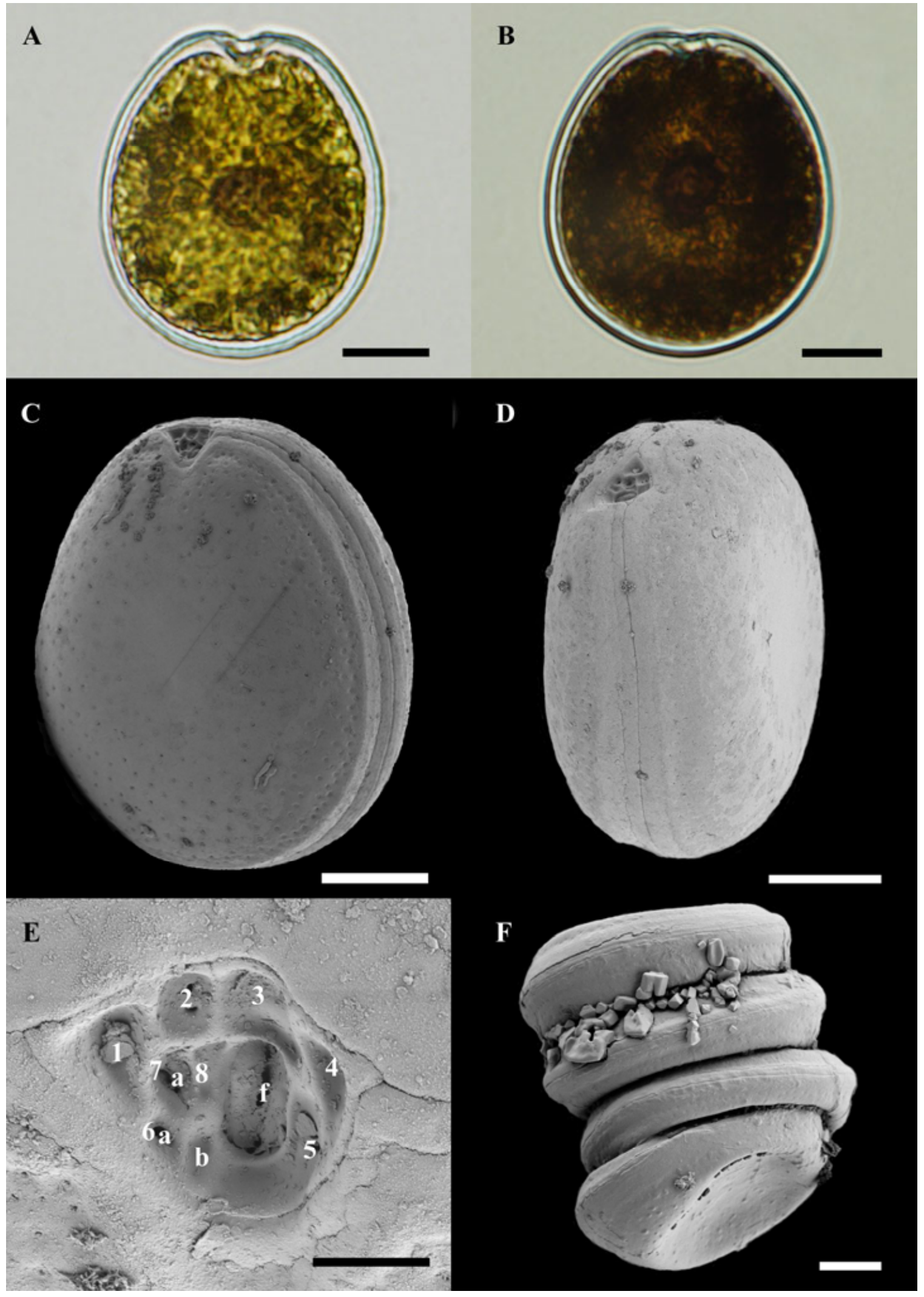

This article is protected by copyright. All rights reserved. 


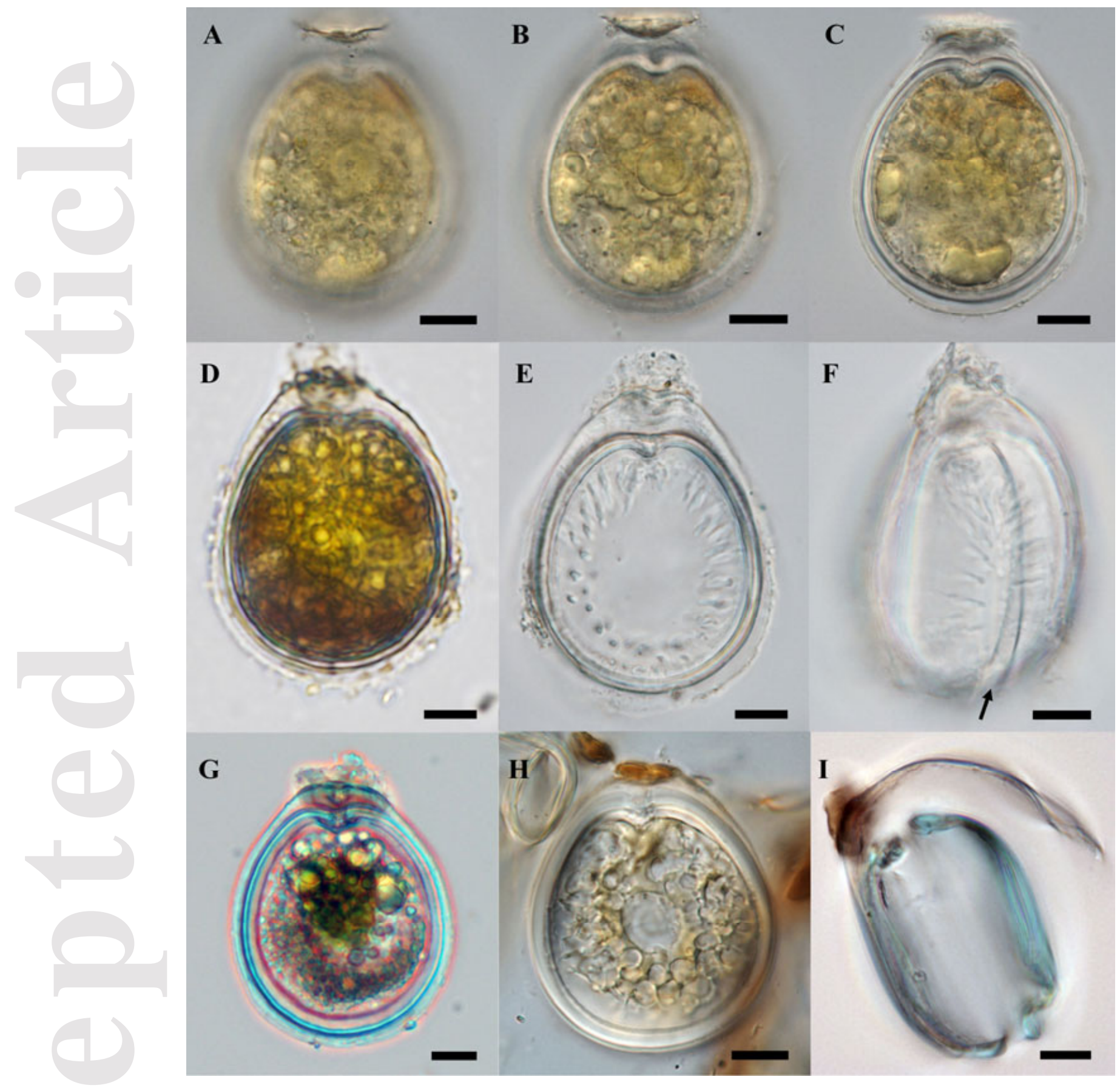

This article is protected by copyright. All rights reserved. 


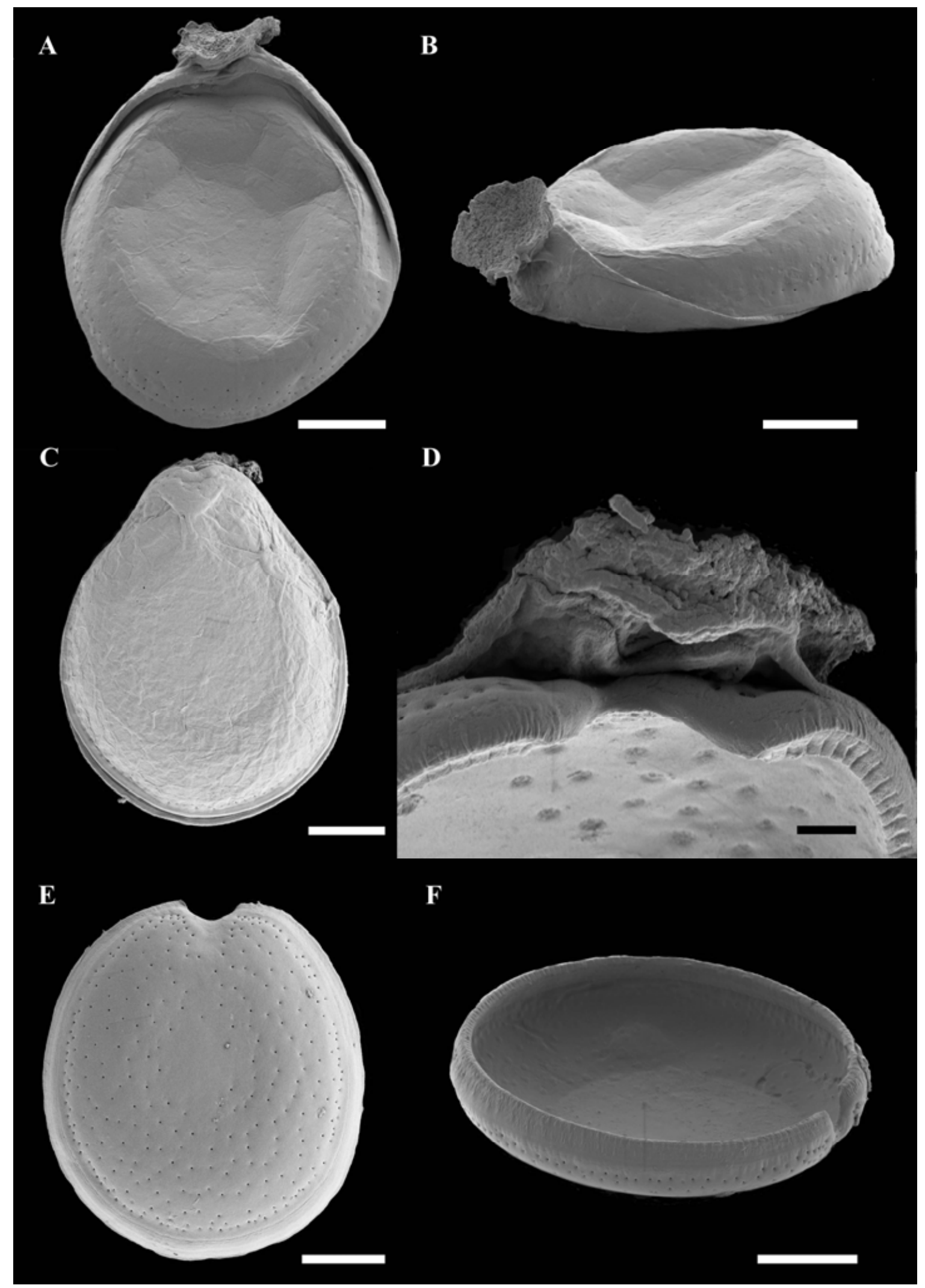

This article is protected by copyright. All rights reserved. 

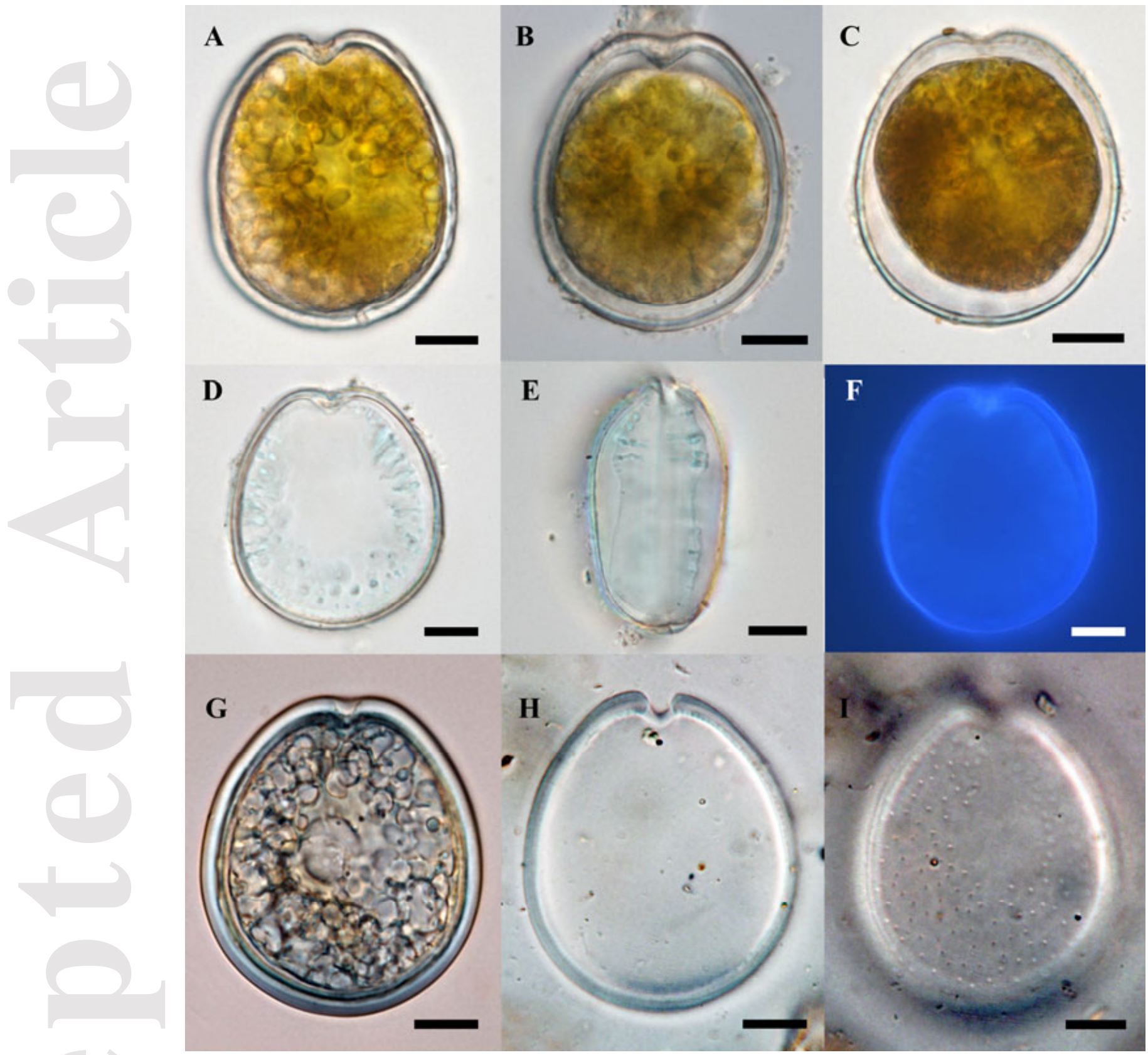

This article is protected by copyright. All rights reserved. 


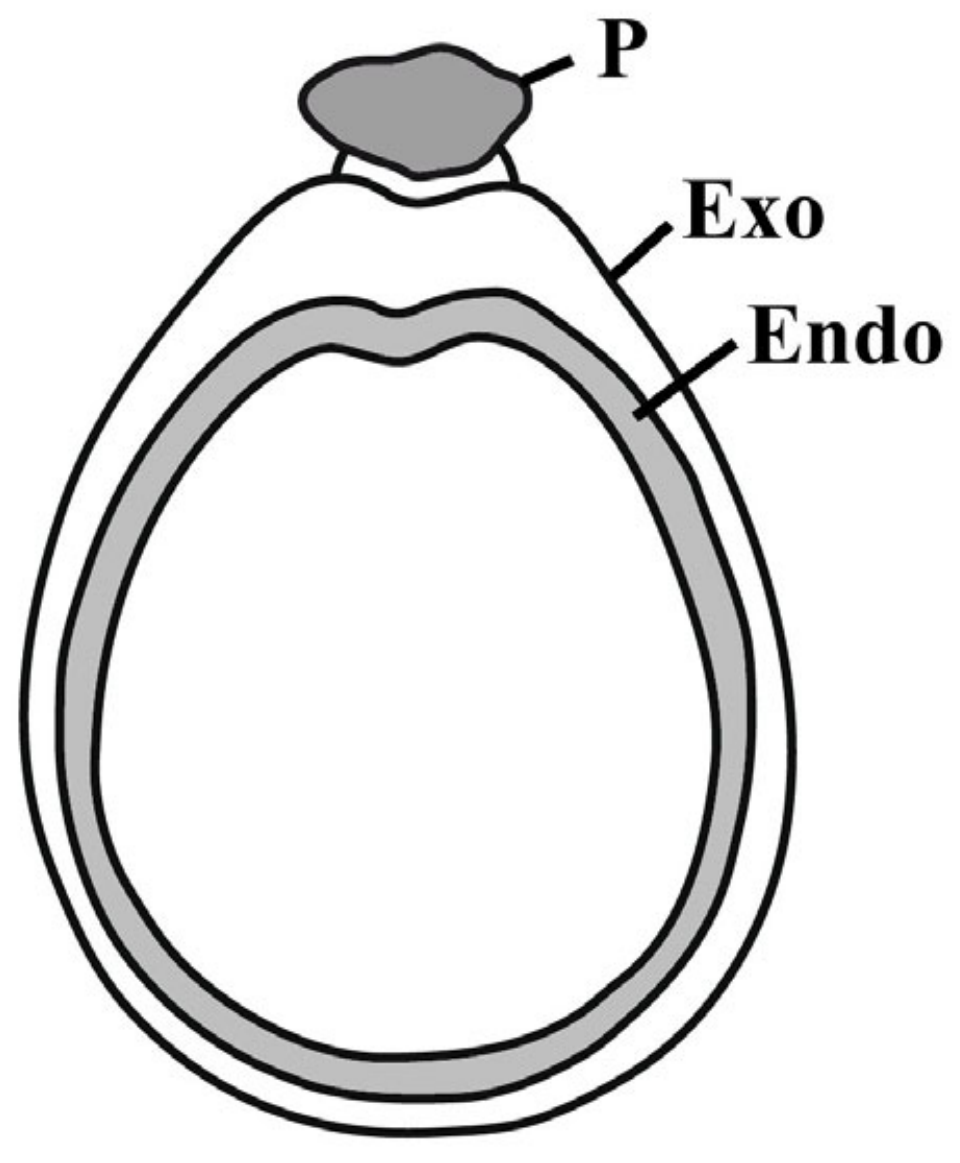

This article is protected by copyright. All rights reserved. 

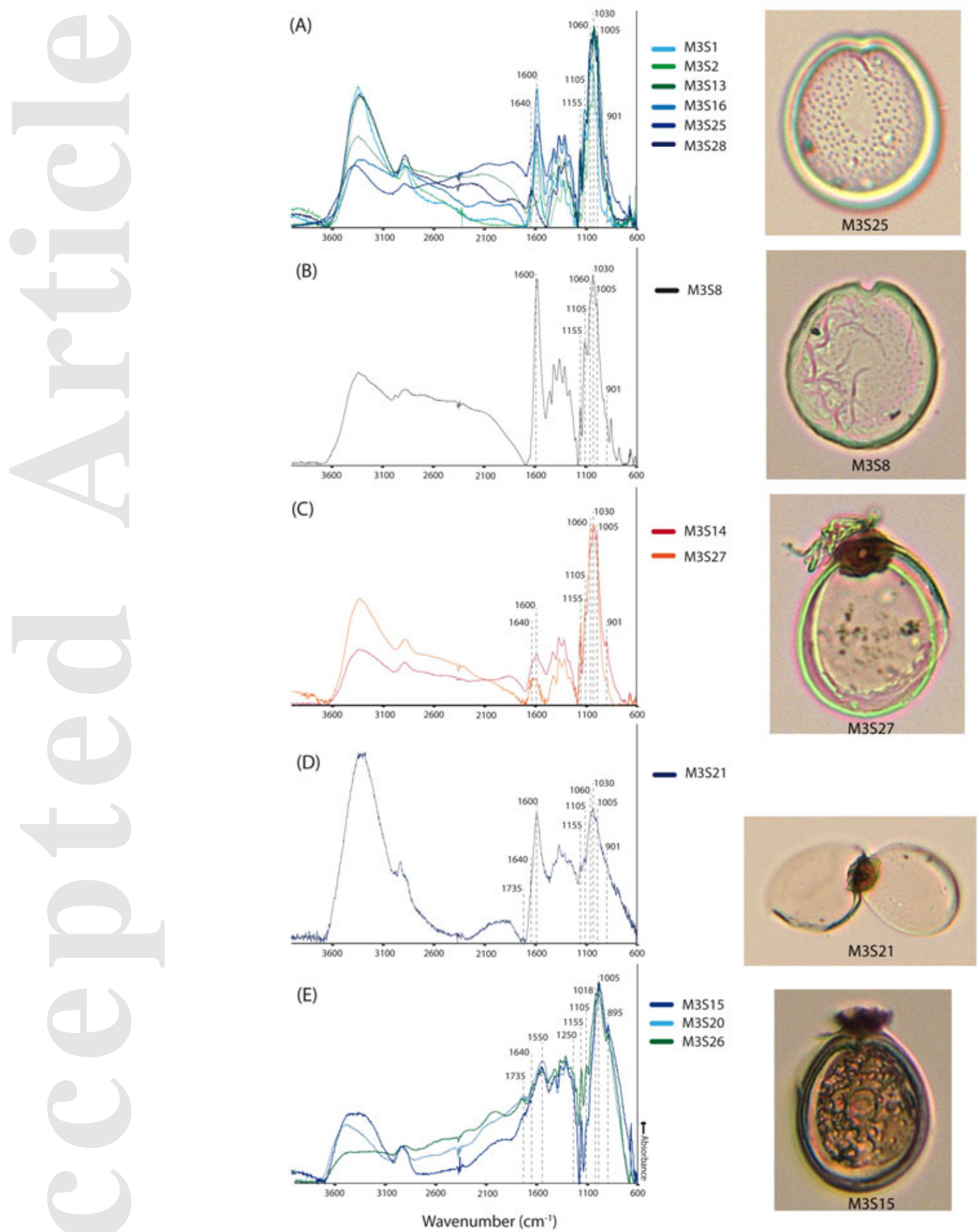

This article is protected by copyright. All rights reserved. 


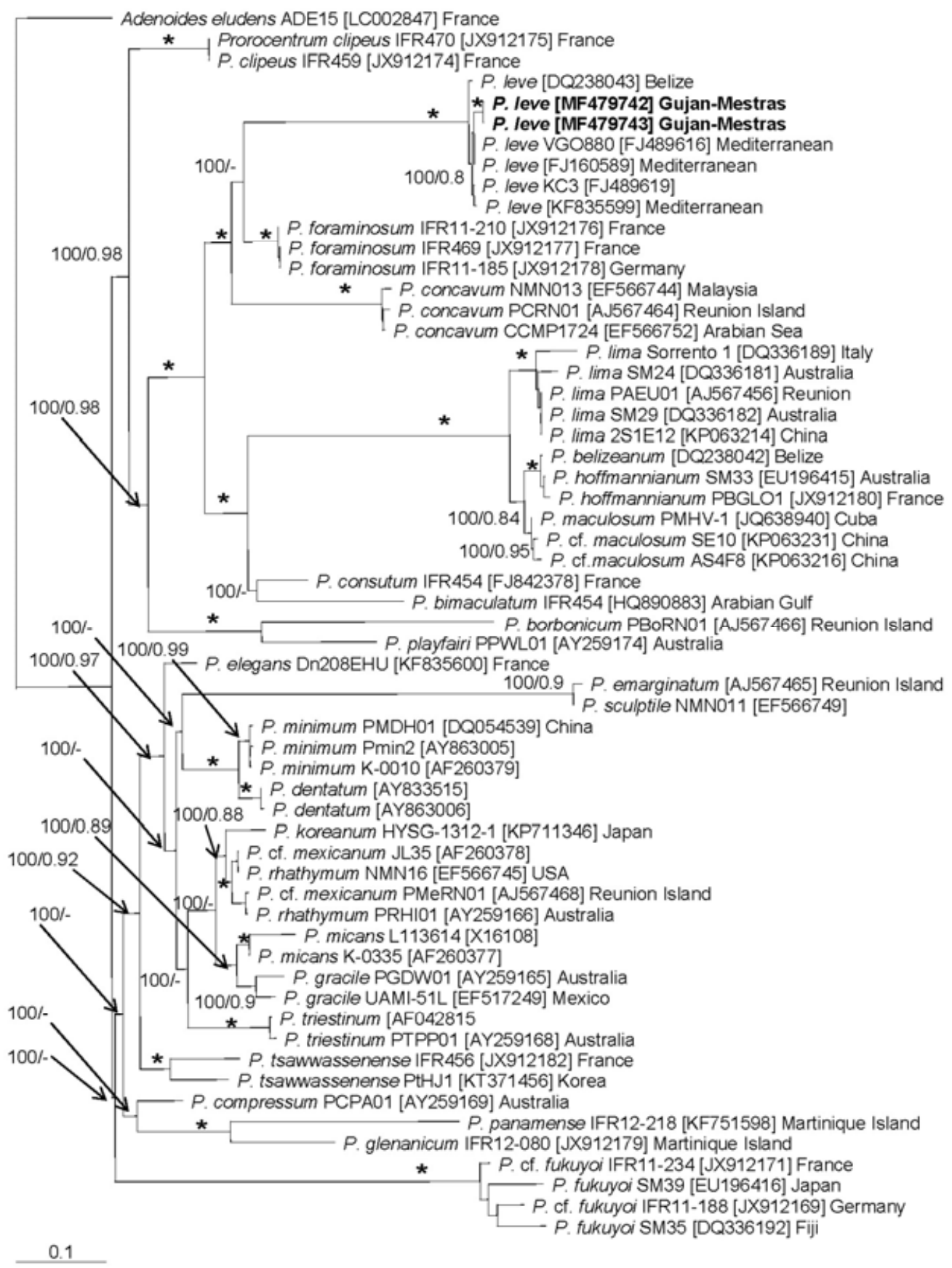

This article is protected by copyright. All rights reserved. 